\title{
Dwarf shrubs are stronger competitors than graminoid species at high nutrient supply in peat bogs
}

\author{
Ada Kool · Monique M. P. D. Heijmans
}

Received: 29 August 2008/Accepted: 6 January 2009/Published online: 15 May 2009

(C) The Author(s) 2009. This article is published with open access at Springerlink.com

\begin{abstract}
Climate warming is likely to increase nutrient mineralization rates in bog ecosystems which may change the plant species composition. We examined the competitive relationships between two graminoid species, Eriophorum vaginatum and Rhynchospora alba, and two ericoid species, Calluna vulgaris and Vaccinium oxycoccus, at different nutrient supply rates. In a greenhouse, the plants were grown in monocultures and mixtures at four nutrient treatments: control, high $\mathrm{N}$, high $\mathrm{P}$, and high $\mathrm{N}+\mathrm{P}$. The results show that the ericoids responded more strongly to the nutrient treatments than the graminoids. The dwarf shrubs showed higher growth rates and reduced root:shoot ratio at high $\mathrm{N}+\mathrm{P}$ supply. When grown in mixture the ericoids increased their growth, while graminoids decreased in biomass or showed signs of nutrient limitation compared to their monoculture plants. This suggests that under increased nutrient availability, bogs are more likely to turn into dwarf shrub dominated ecosystems and not grassland.
\end{abstract}

Keywords Climate warming - Competition . Ericoids - Mire vegetation - Nitrogen deposition . Peatlands

A. Kool · M. M. P. D. Heijmans ( $\square)$

Nature Conservation and Plant Ecology Group, Wageningen University, Droevendaalsesteeg 3A, 6708 PB Wageningen, The Netherlands

e-mail: monique.heijmans@wur.nl

\section{Introduction}

Global change is expected to affect structure and functioning of several types of ecosystems, including bogs (Gorham 1991; Bridgham et al. 1995). Bog ecosystems function as long-term terrestrial carbon sinks and contain a large fraction of the global soil carbon pool (Gorham 1991; Wieder and Vitt 2006). In these ecosystems, potential effects of global change might be of enormous importance, as the carbon sink capacity may be reduced or even changed into a carbon source (Bridgham et al. 1995).

The sequestration of atmospheric carbon in bogs is caused by extremely slow litter decomposition, resulting in peat formation. Species of the genus Sphagnum are dominant in bog ecosystems and play a major role in this process of peat accumulation. Sphagnum reduces the amount of available nutrients in the ecosystem both by producing litter of a poor quality, which favors slow decomposition, and by intercepting atmospheric nutrients (Berendse et al. 2001; Limpens et al. 2004; Bragazza et al. 2006). By keeping the amount of available nutrients in the ecosystem low, Sphagnum restricts the number of vascular plants. Vascular plants produce litter of much higher quality and would therefore reduce the ability of the ecosystem to form peat (Wieder and Vitt 2006).

Temperature rise as expected under the global change scenarios is likely to increase mineralization rates (Nadelhoffer et al. 1991). Consequently, a 
higher amount of soil nitrogen $(\mathrm{N})$ and phosphorus (P) will become available for the vegetation. Several studies showed that the enhanced nutrient availability in bog ecosystems causes an increase in vascular plant cover (Berendse et al. 2001; Heijmans et al. 2001; Limpens et al. 2003; Wiedermann et al. 2007; Gerdol et al. 2008), while it negatively affects Sphagnum biomass (Berendse et al. 2001; Chapin et al. 2004; Bubier et al. 2007; Wiedermann et al. 2007). The expansion of vascular plants in bog systems caused by enhanced mineralization rates might cause the same positive feedback as described by Lamers et al. (2000) for N deposition. Decomposition and $\mathrm{N}$ mineralization are stimulated as a result of easily decomposable vascular plant litter. Furthermore, the roots of vascular plants excrete oxygen and organic substances which also stimulates mineralization and decomposition (Lamers et al. 2000). This feedback may further increase vascular plant expansion and may ultimately change the structure and composition of bog ecosystems.

Generally, enhanced nutrient levels in plant communities lead to increased plant productivity and decreased species richness (Gough et al. 2000; Stevens et al. 2004). In environments with sufficient nutrients, plants with a high potential growth rate and a high leaf area ratio (the leaf area per unit total plant biomass) will have advantages over plants with lower potential growth rate (Berendse 1994; Lambers et al. 1998). This might explain why graminoids often increase in abundance after the application of fertilizer (Graglia et al. 2001; Van Wijk et al. 2003; Bret-Harte et al. 2004, 2008). In bog ecosystems, a shift in dominance from one plant functional group toward another might have great impact. Dorrepaal et al. (2005) found that there are large differences in litter quality between functional groups of plants and therefore concluded that on the long-term changes in relative abundance of plant functional groups might be more important than the direct impacts of environmental change, like $\mathrm{N}$ deposition. Therefore, it is important to determine the response of the different functional groups on enhanced nutrient availability and to determine the outcome of competition between these two growth forms. On account of the expected increase of vascular plants under the current global change scenarios, more knowledge about the response of vascular plants to increased $\mathrm{N}$ and $\mathrm{P}$ levels and the competition between the different functional groups is needed in order to predict the changes in ecosystem's structure and functioning.

This study focuses on the effects of increased $\mathrm{N}$ and $P$ levels on growth and resource allocation of the evergreen Ericaceous shrubs $C$. vulgaris (L.) Hull and $V$. oxycoccus $\mathrm{L}$. and the graminoids $E$. vaginatum $\mathrm{L}$. and $R$. alba (L.) Vahl in a greenhouse experiment. Furthermore the effects of increased $\mathrm{N}$ and $\mathrm{P}$ availability on the competitive relation between $C$. vulgaris and E. vaginatum, and between $V$. oxycoccus and $R$. alba were studied. The following hypotheses were tested: (1) Both graminoids and ericoids show increased growth after the application of $\mathrm{N}$ and $\mathrm{P}$ (however, graminoids increase the most) (2) Graminoids will outcompete ericoids (more clearly) at enhanced $\mathrm{N}$ and $\mathrm{P}$ availability.

\section{Materials and methods}

\section{Plant material}

In order to determine the effects of increased $\mathrm{N}$ levels and increased $\mathrm{P}$ levels on the functional groups of graminoids and ericaceous shrubs from bog ecosystems, as well as on the competition between these groups, two species pairs were selected. The pairs comprised a graminoid species and an ericaceous shrub co-occurring on relatively wet sites and one pair co-occurring on relatively dry parts of the bog. Based on these criteria, we selected the ericaceous shrub C. vulgaris and the graminoid species E. vaginatum from relatively dry sites, and $V$. oxycoccus and $R$. alba from relatively wet sites. These four species are common in undisturbed bogs and can be seen as representative species for ombrotrophic mires.

The plant material was collected from a small mire situated in the state Forestry Dwingeloo $\left(52^{\circ} 49^{\prime} \mathrm{N}\right.$, $6^{\circ} 25^{\prime} \mathrm{E}$ ), in the northeast of the Netherlands. Vegetation at the collection sites was mainly dominated by three Sphagnum species; S. fallax, S. magellanicum and S. papillosum. Mean annual precipitation is $859 \mathrm{~mm}$ and the mean annual temperature is $9.2^{\circ} \mathrm{C}$. The total annual $\mathrm{N}$ deposition over 2006 was $3.5 \mathrm{~g} \mathrm{~N} / \mathrm{m}^{2}$ in this part of the Netherlands, which is not particularly high for this country, but is high compared to other regions with peatlands (Limpens et al. 2006). Collection of the plants took place at the end of 
October, 2007. We carefully collected shoots, including fine roots, of the species E. vaginatum, $V$. oxycoccus and $C$. vulgaris, and the winter buds of $R$. alba. The shoots and the winter buds were transported in plastic bags and stored in a fridge at $7^{\circ} \mathrm{C}$ for only $1-6$ days, until the start of the greenhouse experiment.

\section{Experimental set-up}

To study the effects of increased $\mathrm{N}$ and $\mathrm{P}$ availability on growth and resource allocation of the individual species, monocultures of all four species were grown at four different nutrient treatments: control treatment, high $\mathrm{N}$ treatment, high $\mathrm{P}$ treatment, and high $\mathrm{N}+\mathrm{P}$ treatment. To investigate the competitive outcome between graminoid E. vaginatum and ericaceous shrub $C$. vulgaris and graminoid $R$. alba and ericaceous shrub $V$. oxycoccus at different nutrient supplies, a replacement experiment was used. Both species pairs were grown in a 50-50\% mixture at the same four nutrient treatments as applied in monocultures. All treatments were replicated five times.

We chose for an experiment under controlled conditions, by using aqueous nutrient solutions, to be sure that the added nutrients were directly available to the plants. Measurements of the nutrient concentrations in the pot solution during the experiment confirmed that the treatments differed in nutrient availability (data not shown). When this experiment would have been conducted on a peaty substrate, as in the field, the nutrients would probably have been immobilized and would have become available only after some time. This could take about one year as in a field fertilization experiment described by Van der Hoek et al. (2004). This study therefore addresses direct competition for nutrients in inorganic form.

Shoots of each plant species were placed in notches in a rubbery disc with a diameter of $125 \mathrm{~mm}$, with a total amount of four shoots per disc. These discs were placed on 11 pots. Consequently, the monocultures contained four plant shoots of the same species, while the mixtures contained two shoots of a graminoid species and two shoots of its paired ericaceous shrub. Subsequently, all pots were filled with $950 \mathrm{~g}$ of artificial rainwater solution, an 8,000 -fold dilution of a sea water solution based on Garrels and Christ (1965). The amount of artificial rainwater in the pots was kept constant during the experiment, nullifying the water loss by replenishing water once a week. The pots were arranged in five blocks, corresponding to the number of replicates, with a total number of 120 pots, and were randomly rearranged every 2 weeks to minimize the effect of position within the greenhouse compartment.

$\mathrm{N}$ and $\mathrm{P}$ were applied to all four nutrient treatments once a week. The control treatment received $1.0 \mathrm{~g} \mathrm{~N}$ $\mathrm{m}^{-2} \mathrm{y}^{-1}$ and $0.05 \mathrm{~g} \mathrm{P} \mathrm{m}^{-2} \mathrm{y}^{-1}$, the high $\mathrm{N}$ treatment got $5.0 \mathrm{~g} \mathrm{~N} \mathrm{~m}^{-2} \mathrm{y}^{-1}$ and $0.05 \mathrm{~g} \mathrm{P} \mathrm{m}^{-2} \mathrm{y}^{-1}$, the high $\mathrm{P}$ treatment got $1.0 \mathrm{~g} \mathrm{~N} \mathrm{~m}^{-2} \mathrm{y}^{-1}$ and $0.25 \mathrm{~g} \mathrm{P} \mathrm{m}^{-2} \mathrm{y}^{-1}$, and the treatment with both high $\mathrm{N}$ and $\mathrm{P}$ received $5.0 \mathrm{~g} \mathrm{~N} \mathrm{~m}^{-2} \mathrm{y}^{-1}$ and $0.25 \mathrm{~g} \mathrm{P} \mathrm{m}^{-2} \mathrm{y}^{-1}$. In addition, an amount of $0.7 \mathrm{~g} \mathrm{~K} \mathrm{~m}^{-2} \mathrm{y}^{-1}$ was added to all nutrient treatments in order to prevent potassium deficiency during the experiment. Nitrogen was applied as $\mathrm{NH}_{4} \mathrm{NO}_{3}, \mathrm{P}$ as $\mathrm{NaH}_{2} \mathrm{PO}_{4} \cdot \mathrm{H}_{2} \mathrm{O}$, and $\mathrm{K}$ was added as $\mathrm{K}_{2} \mathrm{SO}_{4}$. The weekly amount of nutrients each pot received was dissolved in $5 \mathrm{ml}$ demineralized water and directly injected into the artificial rainwater using a $5 \mathrm{ml}$ pipette. By using this method, there is direct competition between the shoots for inorganic nutrients. The total amount of applied $\mathrm{N}$ in the high $\mathrm{N}$ treatments represented a high $\mathrm{N}$ deposition situation, as in the Netherlands during the 1990s, while $1.0 \mathrm{~g} \mathrm{~N} \mathrm{~m}^{-2} \mathrm{y}^{-1}$ is presumed to be a critical $\mathrm{N}$ load for bog ecosystems beyond which the productivity of Sphagnum decreases (Bragazza et al. 2006). The P supply was based on an $\mathrm{N}: \mathrm{P}$ ratio of 20.

The experiment was conducted in a greenhouse in Wageningen, The Netherlands, for a period of 14 weeks, starting at the end of October, 2007. The harvest of the plants took place at the beginning of February, 2008. Temperature in the greenhouse compartment was set at $20^{\circ} \mathrm{C}$ during daytime and $15^{\circ} \mathrm{C}$ at night, with $16 \mathrm{~h}$ of daylight and $8 \mathrm{~h}$ night. In case of low light conditions during daytime, extra light was provided by SON-T lights.

\section{Measurements}

During the experiment, growth rate of the plants was followed by measuring height or length of all shoots every 2 weeks. The average length increment per shoot during the 14 weeks of the experiment is defined as shoot length growth. In addition, the weekly water loss by transpiration was recorded for every pot to use as a proxy for photosynthesis. All pots were weighed on a weekly basis to determine the water loss. In 
addition, the weekly water loss of six pots without plants closed off by rubbery discs identical to the pots used in the experiment was determined. The average evaporation from the six pots was used to correct the water loss of the pots with plants for the amount of water lost by evaporation. Only data from the monocultures could be analyzed for species-specific nutrient treatment effects, as water loss in the mixture pots can not be assigned to the species.

At the end of the experiment all plants were harvested and separated into fine roots and leaf parts. Additionally, for the ericaceous shrubs, the stem was separated as well as the young and old leaves. To determine the leaf area ratio (LAR, leaf area/total plant dry weight, in other words the leaf area per unit total plant biomass) and the specific leaf area (SLA, leaf area/leaf dry weight, a measure of leaf thickness) of the plants, fresh leaves were scanned with a HP scanner and the leaf surface area was calculated using the computer program ImageJ (version 1.39). All plant parts were dried in a drying oven for at least $48 \mathrm{~h}$ at $70^{\circ} \mathrm{C}$ and dry weight was determined. The root:shoot ratio of the plants was defined as the ratio of fine roots and leaves.

After the biomass measurements, all leaves were grinded and analyzed for $\mathrm{N}$ and $\mathrm{P}$ concentration. Measurements of these elements were carried out after destruction with a mixture of $\mathrm{H}_{2} \mathrm{SO}_{4}, \mathrm{Se}$, and salicylic acid, and were analyzed with a Skalar Sanplus autoanalyzer. The amount of plant material per pot was insufficient to carry out the chemical analyses, therefore the five replicates of each treatment were pooled and analyzed as one sample.
Statistical analysis

All statistical analyses were carried out in SPSS (version 12.0). Data were tested for normality with a Kolmogorov-Smirnov test and for homogeneity of variances with Levene's test. In case of not normally distributed data or heterogeneity of variances, data were transformed using square-root transformation. A Kruskal-Wallis test was used to analyze data that showed a non-normal distribution or heterogeneity of variances after transformation. To test the influence of both nutrient treatment and competition treatment on the attributes of the four species, 2-factor ANOVA's were used, with a Tukey post-hoc test or, in case of an unequal sample size, a Scheffe posthoc test. N:P ratios in old and young leaves of the ericoids were compared with a paired $t$-test. Differences among the nutrient treatments in leaf N:P ratio and water loss by transpiration between the treatments were tested with an one-way ANOVA and a Tukey post-hoc test.

\section{Results}

Effects of nutrient treatments

Both ericoid species responded to the application of both $\mathrm{N}$ and $\mathrm{P}$. Although $C$. vulgaris shoots grown in the control treatment reached highest biomass values (Fig. 1), differing significantly from shoots of the high $\mathrm{N}$ and high $\mathrm{P}$ treatments (Table 1), shoot length growth was largest in the high $\mathrm{N}+\mathrm{P}$ treatment for
Fig. 1 Average biomass per shoot $( \pm 1 \mathrm{SE}, n=5$ pots) of C. vulgaris,

E. vaginatum, $V$. oxycoccus and $R$. alba after 14 weeks of nutrient and competition treatments
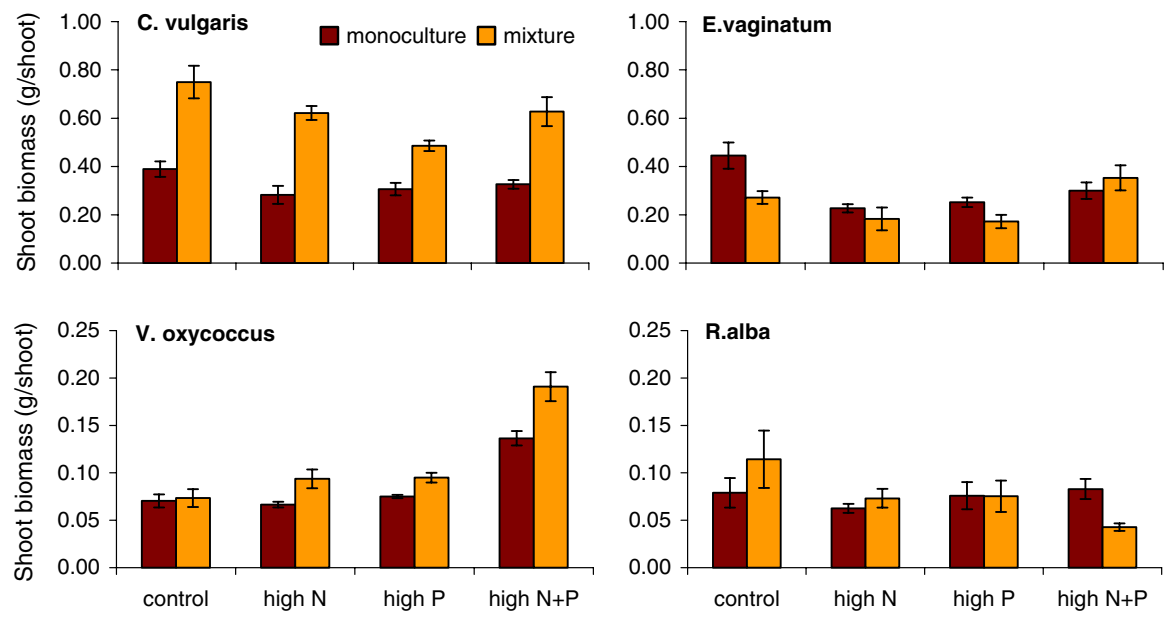
Table 1 Overview of nutrient and competition treatment effects on the plant characteristics biomass, shoot growth rate, transpiration, root:shoot ratio, leaf area ratio, and specific leaf area of the four study species

\begin{tabular}{|c|c|c|c|c|c|c|c|c|}
\hline \multirow[t]{2}{*}{ Measurement } & \multicolumn{3}{|c|}{ Nutrient effect } & \multicolumn{3}{|c|}{ Competition effect } & \multicolumn{2}{|c|}{ Interaction } \\
\hline & $F_{3,31-32}$ & $P$ & Posthoc & $F_{1,31-32}$ & $P$ & Posthoc & $F_{3,31-32}$ & $P$ \\
\hline \multicolumn{9}{|l|}{ C. vulgaris } \\
\hline Biomass & 6.47 & 0.002 & $\mathrm{c}>\mathrm{n}, \mathrm{p}$ & 5.25 & $<0.001$ & $\operatorname{mix}>\operatorname{mo}$ & 2.02 & 0.131 \\
\hline Shoot length growth & 17.64 & $<0.001$ & $\mathrm{np}>\mathrm{c}, \mathrm{n}, \mathrm{p}$ & 11.69 & 0.002 & $\operatorname{mix}>\operatorname{mo}$ & 0.53 & 0.663 \\
\hline Transpiration & 5.58 & 0.008 & $\mathrm{np}>\mathrm{p}$ & & & & & \\
\hline Root:shoot ratio & 5.01 & 0.006 & $\mathrm{c}>\mathrm{np}$ & 1.72 & 0.199 & & 0.74 & 0.538 \\
\hline Leaf area ratio & 6.08 & 0.002 & $\mathrm{n}, \mathrm{np}>\mathrm{c}$ & 0.24 & 0.629 & & 1.44 & 0.250 \\
\hline Specific leaf area & 19.11 & $<0.001$ & & 4.52 & 0.009 & & 4.52 & 0.009 \\
\hline \multicolumn{9}{|l|}{ V. oxycoccus } \\
\hline Biomass & 52.17 & $<0.001$ & & 18.78 & $<0.001$ & & 3.38 & $\mathbf{0 . 0 3 1}$ \\
\hline Shoot growth rate & 14.61 & $<0.001$ & $\mathrm{np}>\mathrm{c}, \mathrm{n}, \mathrm{p}$ & 6.37 & 0.017 & $\operatorname{mix}>\operatorname{mo}$ & 2.26 & 0.101 \\
\hline Transpiration & 13.25 & $<0.001$ & $\mathrm{np}>\mathrm{c}, \mathrm{n}, \mathrm{p}$ & & & & & \\
\hline Root:shoot ratio & 6.19 & 0.002 & $c>p$ & 0.01 & 0.922 & & 0.48 & 0.700 \\
\hline Leaf area ratio & 3.79 & 0.020 & $\mathrm{np}>\mathrm{c}$ & 3.66 & 0.065 & & 0.22 & 0.882 \\
\hline \multicolumn{9}{|l|}{ E. vaginatum } \\
\hline Biomass & 8.69 & $<0.001$ & & 5.25 & 0.029 & & 3.10 & 0.040 \\
\hline Leaf area ratio & 2.84 & 0.053 & & 0.03 & 0.860 & & 4.31 & 0.012 \\
\hline Specific leaf area & 2.71 & 0.061 & & 0.03 & 0.866 & & 3.51 & 0.026 \\
\hline \multicolumn{9}{|l|}{ R. alba } \\
\hline Leaf area ratio & 1.48 & 0.239 & & 17.25 & $<0.001$ & $\operatorname{mo}>\operatorname{mix}$ & 2.00 & 0.136 \\
\hline Specific leaf area & 1.67 & 0.193 & & 16.36 & $<0.001$ & $\operatorname{mo}>\operatorname{mix}$ & 1.66 & 0.196 \\
\hline
\end{tabular}

Significant treatment effects $(P<0.05)$ are in bold. Plant characteristics with no significant treatment effects are not shown Treatment codes: $c$ control, $n$ high $\mathrm{N}, p$ high $\mathrm{P}, n p$ high $\mathrm{N}+\mathrm{P}$, mix mixtures, mo monocultures

For transpiration $\mathrm{df}=3,17$

this species (Fig. 2). Addition of both $\mathrm{N}$ and $\mathrm{P}$ in $V$. oxycoccus led to higher biomass (Fig. 1) and an increased shoot length growth (Fig. 2) compared to all other treatments. Shoots of $V$. oxycoccus grown in treatments with either high $\mathrm{P}$ or high $\mathrm{N}$ alone did not differ from the control in the measured plant

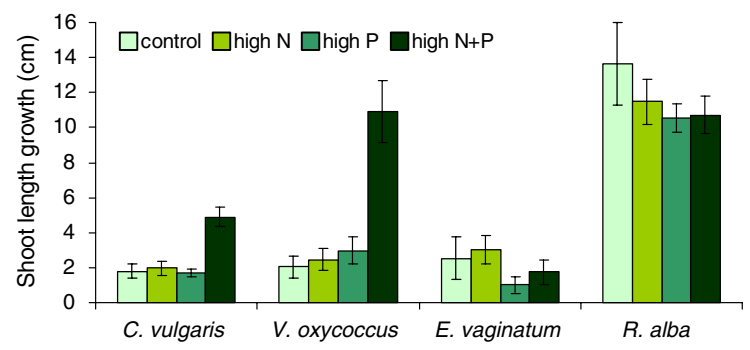

Fig. 2 Average shoot length growth $(\mathrm{cm})$ over 14 weeks $( \pm 1$ SE, $n=10$ pots) of E. vaginatum, R. alba, C. vulgaris, and $V$. oxycoccus grown in four nutrient treatments characteristics (Table 1). Similar to shoot length growth, water loss by transpiration of the monoculture plants was largest in the high $\mathrm{N}+\mathrm{P}$ treatment for both ericaceous species (Table 1). Transpiration of $V$. oxycoccus during the experiment was $57 \%$ higher in the high $\mathrm{N}+\mathrm{P}$ treatment when compared to the control (data not shown).

Both graminoid species did not show large responses to the nutrient treatments. However, E. vaginatum had a higher biomass in the control (monocultures) and in the high $\mathrm{N}+\mathrm{P}$ treatment (mixtures) when compared to high $\mathrm{N}$ and high $\mathrm{P}$ treatments (Fig. 1; Table 1). This was not confirmed by nutrient treatment effects on shoot length growth or water loss by transpiration (Table 1). For $R$. alba about $12 \%$ of the winterbuds had failed to develop roots after the final measurements at 14 weeks. The type of treatment had no influence on the success of root development. Undeveloped buds were not taken 
into account for the calculation of the shoot length growth, but were included in total biomass. No nutrient treatment effects were found for this species (Fig. 1; Table 1).

Resource allocation patterns changed for some of the species after the application of extra nutrients. Leaf area ratios of $C$. vulgaris and $V$. oxycoccus were affected by the nutrient treatments. For $C$. vulgaris, high $\mathrm{N}$ and high $\mathrm{N}+\mathrm{P}$ supply led to relatively more leaf area, while $V$. oxycoccus shoots showed relatively more leaf area in the high $\mathrm{N}+\mathrm{P}$ treatment when compared to the control treatment (Fig. 3). Also, both species showed a decreased root:shoot ratio at high $\mathrm{N}+\mathrm{P}$ when compared to , repectively, the control treatment or the high $\mathrm{P}$ treatment. In contrast, both E. vaginatum and $R$. alba showed no response in specific leaf area, relative amount of leaf area (LAR) (Fig. 3) or root:shoot ratio with respect to the nutrient treatments (Table 1).

Except for E. vaginatum, all species showed a response in foliar $\mathrm{N}$ and $\mathrm{P}$ concentration after application of additional nutrients (data not shown). In both $C$. vulgaris and $R$. alba the N:P ratio of the leaves was significantly lower in the high $\mathrm{N}+\mathrm{P}$ and high $\mathrm{P}$ treatment than in the control and high $\mathrm{N}$ treatment (ANOVA's, $F=142.74$, df $=3$ with $P<0.001$ and $F=35.32$, df $=3$ with $P=0.002$ for $C$. vulgaris and $R$. alba, respectively). In $V$. oxycoccus the $\mathrm{N}: \mathrm{P}$ ratio in the leaves was lower for shoots grown in the high $\mathrm{P}$ treatment compared to the other treatments (ANOVA, $F=57.32$, df $=3, P=$ 0.001). C. vulgaris and V. oxycoccus showed a much higher N:P ratio in old leaves when compared to the ratio in young leaves (paired $t$-tests, $t=5.12$, $\mathrm{df}=3$, $P=0.001$ for $C$. vulgaris and $t=7.00, \mathrm{df}=3$, $P<0.001$ for $V$. oxycoccus).

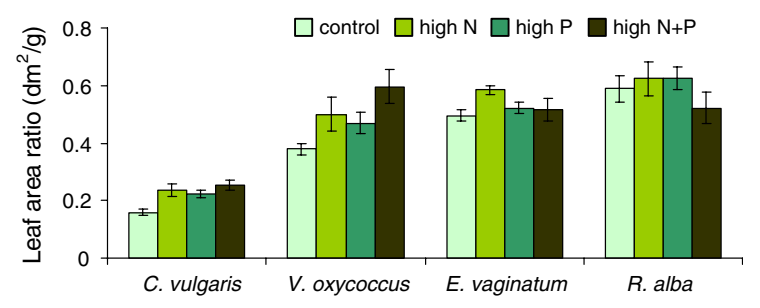

Fig. 3 Average leaf area ratio $\left(\mathrm{dm}^{2} / \mathrm{g}\right)$ values $( \pm 1 \mathrm{SE}, n=10$ pots) of E. vaginatum, R. alba, C. vulgaris, and V. oxycoccus grown in four nutrient treatments
Effects of competition treatment

E. vaginatum was significantly affected in biomass by the competition from $C$. vulgaris. Shoots grown in mixture had $25 \%$ less biomass than shoots grown in monoculture (Fig. 1). On the other hand, C. vulgaris showed an increased biomass of $90 \%$ when grown in a mixture together with $E$. vaginatum when compared to the monocultures (Fig. 1) and had a higher shoot length growth in mixtures.

$R$. alba showed no differences in terms of biomass or shoot length growth between shoots grown in mixture together with ericoid $V$. oxycoccus and shoots grown in monoculture. However, V. oxycoccus showed a $31 \%$ higher biomass in mixtures than in monocultures and shoot length growth was also higher in mixtures. The interaction effect between nutrient treatment and competition treatment in biomass of $V$. oxycoccus shows that the difference between the mixture and the monoculture depended on the nutrient treatment. The high $\mathrm{N}+\mathrm{P}$ treatment showed the largest difference between mixture and monoculture, while there was no such difference in the control treatment (Table 1; Fig. 1).

In terms of resource allocation, two species responded to the presence of the co-occurring species. R. alba had relatively less leaf area and thicker leaves (lower SLA) in mixtures with V. oxycoccus when compared to monocultures (Fig. 4). In contrast, C. vulgaris produced thinner leaves in mixtures with E. vaginatum than in monocultures (Fig. 4). Interaction between nutrient treatment and competition treatment effects was found in C. vulgaris for specific leaf area. When more nutrients were added the difference in SLA between the mixture and monoculture increased (Fig. 5).

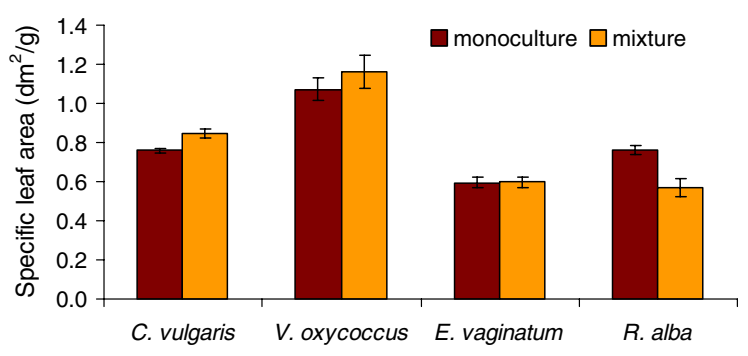

Fig. 4 Average values ( $\pm 1 \mathrm{SE}, n=20$ pots) of specific leaf area $\left(\mathrm{dm}^{2} / \mathrm{g}\right)$ of E. vaginatum, R. alba, C. vulgaris, and $V$. oxycoccus plants grown in monoculture and mixture 
Fig. 5 Average values of specific leaf area $( \pm 1 \mathrm{SE}$, $n=5$ pots) for $C$. vulgaris and $E$. vaginatum shoots grown in monoculture and mixture at four nutrient treatments

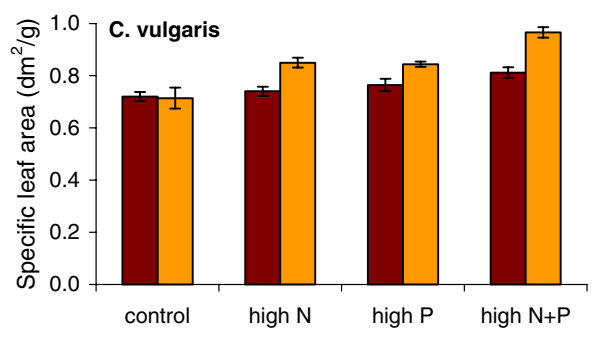

\section{Discussion}

\section{Graminoids}

The results show that both graminoid species were not largely influenced in growth or resource allocation by the application of $\mathrm{N}$ and $\mathrm{P}$, which is not in accordance with our hypothesis. E. vaginatum monocultures even showed the highest biomass in the control treatment, but this was not confirmed by results on shoot length growth or transpiration. We can not exclude the possibility that differences in starting material contributed to the treatment effects on biomass, as we do not have data on starting biomass. However, for initial shoot length there were no significant differences among the treatments. In $C$. vulgaris, biomass was also largest in the control treatment, which was related to the largest fine root biomass. The responses to treatments were more consistent for shoot length growth and other plant characteristics (LAR, SLA, and root:shoot ratio) when related to the allocation of resources to leaves. As the investment in leaf area enables more carbon assimilation for a longer time period, the measured plant characteristics probably better reflect competitive strength than the measured plant biomass after 14 weeks of treatment.

For $R$. alba, the second graminoid species, no differences were found in growth or resource allocation after the application of $\mathrm{N}$ and P. Possibly, the use of winter buds for this species influenced the results, as in winter buds nutrients are stored (Ohlson and Malmer 1990) Plants that store nutrients are less dependent on current photosynthesis and nutrient availability in the soil (Lambers et al. 1998). Consequently, R. alba might be less dependent on the applied nutrients for its growth and therefore did not show a response to the added $\mathrm{N}$ and $\mathrm{P}$. The $\mathrm{N}: \mathrm{P}$ ratio in the leaves, however, differed among the nutrient treatments, suggesting that $R$. alba did use the nutrients to some extent. Studies of
Heijmans et al. (2002); Limpens et al. (2003) found an increase in $R$. alba biomass after $\mathrm{N}$ fertilization in intact bog vegetation. Interestingly, both studies determined the increase in this species during the second growing season of the study. It might be that differences between the nutrient treatments will only become visible in a next growing season.

The lack of graminoid response to the application of $\mathrm{N}$ and $\mathrm{P}$ during this study does not stand on its own. Tomassen et al. (2004) performed a 3-year fertilization study in bog vegetation in Ireland and found that E. vaginatum did not respond to $\mathrm{N}$ addition, however, it was suggested that this was probably attributable to $\mathrm{P}$ limitation. Additionally, Chapin et al. (2004) found that after 3 years of fertilization treatments, graminoids did not respond to any fertilization treatment in a bog in northern Minnesota, USA.

In contrast, other studies showed large responses to fertilizer applications in graminoids. In a tundra ecosystem in Northern Sweden, Graglia et al. (2001) showed in a 10-year fertilization experiment that grasses increased in abundance in response to fertilizer application. Similarly, Van Wijk et al. (2003) reported that the biomass of deciduous shrub and graminoid plant types responded most strongly to nutrient addition on sites in Alaska and Northern Sweden during a long-term fertilization experiment (>3 year). Moreover, Bret-Harte et al. (2004) measured after 2 years in an Alaskan tussock tundra the strongest response to fertilizer in graminoids, of which E. vaginatum was the most dominant graminoid species. However, these studies were performed in tundra ecosystems and not in raised bog ecosystems. Perhaps, there is a difference between tundra and bog in type of nutrient limitation. Bogs with thick peat deposits may be more P-limited, because of the distance to the mineral subsoil (Bedford et al. 1999), while tundra ecosystems are considered to be more N-limited (Shaver and Chapin 1980, 1995). On the 
other hand, our study did not give indications of graminoids being better competitors for either $\mathrm{N}$ or $\mathrm{P}$.

\section{Dwarf shrubs}

In contrast with the findings on the graminoids, both dwarf shrubs showed clear differences in plant characteristics after the application of $\mathrm{N}$ and $\mathrm{P}$. The increase in shoot growth after the application of both $\mathrm{N}$ and $\mathrm{P}$ in $C$. vulgaris and $V$. oxycoccus implies that at least part of the extra available nutrients is allocated to length increase. This is not surprising as vascular plants in bogs need to keep up with the rising Sphagnum surface to avoid being overgrown (Malmer et al. 1994). Additionally, some studies suggest that shading, enhanced by increased shoot growth, can have a negative impact on Sphagnum growth (Jonasson et al. 1999; Berendse et al. 2001) and even can increase N deposition by canopy interception (Lamers 2000). This would give the dwarf shrub a competitive advantage over Sphagnum at increased shoot growth rates. The lower root:shoot ratio after the application of both $\mathrm{N}$ and $\mathrm{P}$ in both $C$. vulgaris and $V$. oxycoccus indicate a clear shift in resource allocation, and was only detected in the dwarf shrubs. The results suggest that nutrients became less limiting in the treatments with added $\mathrm{N}$ and P. Consequently, plants started to invest more resources in the above ground plant parts at the expense of below ground plant parts to increase the carbon assimilation rate. Moreover, C. vulgaris produced leaves with a higher SLA, in other words leaves with a larger surface area to intercept solar radiation for the same amount of biomass, after the application of both $\mathrm{N}$ and $\mathrm{P}$. Plants grown under nutrient shortage generally produce thicker leaves of longer longevity to reduce nutrient loss, while plants grown under adequate nutrient conditions prefer to produce thinner leaves with high chlorophyll concentrations to enlarge the carbon assimilation rate (Lambers et al. 1998). In addition, the high transpiration rates of $C$. vulgaris and $V$. oxycoccus in the treatment with high $\mathrm{N}$ and $\mathrm{P}$ do indeed suggest that in this treatment carbon assimilation rates were higher.

\section{Nutrient limitation}

In the control treatment, leaf $\mathrm{N}: \mathrm{P}$ ratios for all species except $E$. vaginatum were above 16, the values defined by Koerselman and Meuleman (1996) to identify P limitation. This suggests that $\mathrm{P}$ would be the limiting nutrient for growth. The application of $\mathrm{P}$ caused a shift in the N:P ratio in all species towards an $\mathrm{N}$-limited situation. After adding both $\mathrm{N}$ and $\mathrm{P}$, the $\mathrm{N}: \mathrm{P}$ ratios in the graminoid species suggest $\mathrm{P}$ limitation, while the $\mathrm{N}: \mathrm{P}$ ratios in the dwarf shrubs suggest an $\mathrm{N}$-limited situation. However, as all four species in this study did not respond to the application of $\mathrm{N}$ or $\mathrm{P}$ alone, we cannot conclude which species were more limited by $\mathrm{N}$ or by $\mathrm{P}$. Moreover, all species certainly showed more response after the application of both $\mathrm{N}$ and $\mathrm{P}$ when compared to the addition of either $\mathrm{N}$ or $\mathrm{P}$ only. This suggests that the plants are co-limited by both elements and increased deposition of $\mathrm{N}$ alone is not likely to cause a shift in species composition. Van der Gaag and Heijmans (unpublished data) also concluded after a 12week greenhouse experiment, using mixtures and monocultures of $V$. oxycoccus and Sphagnum magellanicum, that an increase in $\mathrm{N}$ deposition will not cause an increase in biomass of $V$. oxycoccus as long as the amount of $\mathrm{P}$ is limited. In bogs similar to the one used in this study, the availability of $\mathrm{P}$ might ultimately determine the impact of $\mathrm{N}$ deposition. However, increased mineralization rates as a result of global warming are expected to enhance the availability of both $\mathrm{N}$ and $\mathrm{P}$ and might therefore be a larger threat to the carbon sink capacity of bogs than $\mathrm{N}$ deposition.

\section{Competition}

The competition part of the experiment showed that both graminoid species performed less when grown in mixture than in monoculture, while the dwarf shrubs performed better in mixture when compared to the monocultures. Biomass of E. vaginatum was reduced in the presence of $C$. vulgaris, while $R$. alba showed a lower SLA, in other words produced relatively less and thicker leaves, a sign of nutrient limitation (Lambers et al. 1998), in the presence of V. oxycoccus. Enhanced nutrient limitation for the graminoid species in the mixtures might be explained by the lack of response of the grasses to the nutrient applications. Apparently, in mixture the dwarf shrubs were able to react more and faster to the enhanced nutrients, expanding their biomass while depleting the nutrients and causing nutrient shortage for the graminoids. This is supported by the larger SLA in the mixtures for C. vulgaris, which is a sign of nutrient sufficiency (Lambers et al. 1998). 
While our study lasted for 14 weeks, long-term field studies in bog ecosystems showed similar differential responses to enhanced nutrient availability. Weltzin et al. (2003) found in a multiyear mesocosm experiment in northern Minnesota, USA, that graminoids cover decreased by $50 \%$, while shrub cover increased by $50 \%$ by increased soil temperatures, enhancing nutrient mineralization rates. A recent study of Breeuwer et al. (unpublished data) showed that after southward transplantation of intact bog vegetation, graminoid species did not benefit from the enhanced nutrient levels caused by temperature increase and elevated $\mathrm{N}$ deposition. It were the ericoid shrubs that increased in abundance, mainly due to the increase of $V$. oxycoccus and $C$. vulgaris.

\section{Conclusion}

The results of our experiment suggest that the availability of high $\mathrm{N}$ and $\mathrm{P}$ as expected under global warming scenarios (Nadelhoffer et al. 1991) will alter the competition between vascular plant species in peat bog ecosystems. The interactions between nutrient and competition treatments found for specific leaf area in $C$. vulgaris and biomass in $V$. oxycoccus show that competitive vigor increased at higher nutrient availability, which is in contrast with our hypothesis. In the control treatment no differences were found between the monoculture plants and the plants grown in mixture, however, when nutrients were added the difference between plants grown in monoculture and plants grown in mixture increased, indicating that at high nutrient availability both dwarf shrub species became stronger competitors towards graminoids.

Ericoids were more able to respond to the application of $\mathrm{N}$ and $\mathrm{P}$ than the graminoid species. C. vulgaris is known to be very variable in many characteristics and much of this variation is plastic (Gimingham 1960). From this study, it seems that the ericoids have a higher phenotypic plasticity than the graminoids, and are therefore able to adapt fast to the higher nutrient availability. This fast adaptation might include a higher leaf area ratio and lower root:shoot ratio, increasing the plants growth and photosynthesis rate. Again, this enhanced growth might further increase the plants leaf area ratio, causing a positive feedback mechanism. Probably, this mechanism also explains why the ericoid species started to outcompete the graminoids in the mixtures during this experiment. From this research, it can be concluded that under increased nutrient availability, bogs are more likely to turn into dwarf shrub dominated ecosystems than into grassland.

Acknowledgments We thank Juul Limpens and two anonymous reviewers for their valuable comments, Jan van Walsem and Annemarie van Driessche for their help in the laboratory. State forestry service (Staatsbosbeheer) kindly permitted us to collect plant material in national park Dwingelderveld.

Open Access This article is distributed under the terms of the Creative Commons Attribution Noncommercial License which permits any noncommercial use, distribution, and reproduction in any medium, provided the original author(s) and source are credited.

\section{References}

Bedford BL, Walbridge MR, Aldous A (1999) Patterns in nutrient availability and plant diversity of temperate North American wetlands. Ecology 80:2151-2169

Berendse F (1994) Competition between plant populations at low and high nutrient supplies. Oikos 71:253-260. doi: 10.2307/3546273

Berendse F, Van Breemen N, Rydin H (2001) Raised atmospheric $\mathrm{CO}_{2}$ levels and increased $\mathrm{N}$ deposition cause shifts in plant species composition and production in Sphagnum bogs. Glob Chang Biol 7:591-598. doi:10.1046/j.1365-2486.2001.004 33. $\mathrm{x}$

Bragazza L, Freeman C, Jones T et al (2006) Atmospheric nitrogen deposition promotes carbon loss from peat bogs. Proc Natl Acad Sci USA 103:19386-19389. doi:10.1073/ pnas.0606629104

Bret-Harte MS, Garcia EA, Sacre VM et al (2004) Plant and soil responses to neighbour removal and fertilization in Alaskan tussock tundra. J Ecol 92:635-647. doi:10.1111/ j.0022-0477.2004.00902.x

Bret-Harte MS, Mack MC, Goldsmith GR et al (2008) Plant functional types do not predict biomass responses to removal and fertilization in Alaskan tussock tundra. J Ecol 96:713-726. doi:10.1111/j.1365-2745.2008.01378.x

Bridgham SD, Johnston CA, Pastor J et al (1995) Potential feedbacks of Northern wetlands on climate-change-an outline of an approach to predict climate-change impact. Bioscience 45:262-274. doi:10.2307/1312419

Bubier JL, Moore TR, Bledzki LA (2007) Effects of nutrient addition on vegetation and carbon cycling in an ombrotrophic bog. Glob Chang Biol 13:1168-1186. doi:10.1111/ j.1365-2486.2007.01346.x

Chapin CT, Bridgham SD, Pastor J (2004) pH and nutrient effects on above-ground net primary production in a Minnesota, USA bog and fen. Wetlands 24:186-201. doi:10.1672/ 0277-5212(2004)024[0186:PANEOA]2.0.CO;2

Dorrepaal E, Cornelissen JHC, Aerts R et al (2005) Are growth forms consistent predictors of leaf litter quality and decomposability across peatlands along a latitudinal 
gradient? J Ecol 93:817-828. doi:10.1111/j.1365-2745. 2005.01024.x

Garrels RM, Christ CL (1965) Solutions, minerals and equilibria. Harper and Row, New York

Gerdol R, Bragazza L, Brancaleoni L (2008) Heatwave 2003: high summer temperature, rather than experimental fertilization, affects vegetation and $\mathrm{CO}_{2}$ exchange in an alpine bog. New Phytol 179:142-154. doi:10.1111/j.14698137.2008.02429.x

Gimingham CH (1960) Biological flora of the British isles: Calluna vulgaris (L.) Hull. J Ecol 48:455-483. doi:10.2307/ 2257528

Gorham E (1991) Northern peatlands: role in the carbon cycle and probable responses to climatic warming. Ecol Appl 1: 182-195. doi:10.2307/1941811

Gough L, Osenberg CW, Gross KL et al (2000) Fertilization effects on species density and primary productivity in herbaceous plant communities. Oikos 89:428-439. doi:10.1034/ j.1600-0706.2000.890302.x

Graglia E, Jonasson S, Michelsen A et al (2001) Effects of environmental perturbations on abundance of subarctic plants after three, seven and ten years of treatment. Ecography 24: 5-12. doi:10.1034/j.1600-0587.2001.240102.x

Heijmans MMPD, Berendse F, Arp WJ et al (2001) Effects of elevated carbon dioxide and increased nitrogen deposition on bog vegetation in the Netherlands. J Ecol 89:268-279. doi:10.1046/j.1365-2745.2001.00547.x

Heijmans M, Klees H, De Visser W, Berendse F (2002) Response of a Sphagnum bog plant community to elevated $\mathrm{CO}_{2}$ and $\mathrm{N}$ supply. Plant Ecol 162:123-134. doi:10.1023/ A:1020368130679

Jonasson S, Michelsen A, Schmidt IK, Nielsen EV (1999) Responses in microbes and plants to changed temperature, nutrient, and light regimes in the Arctic. Ecology 80: $1828-1843$

Koerselman W, Meuleman AFM (1996) The vegetation N:P ratio: a new tool to detect the nature of nutrient limitation. J Appl Ecol 33:1441-1450. doi:10.2307/2404783

Lambers H, Chapin FS, Pons TL (1998) Plant physiological ecology. Springer-Verlag, New York

Lamers LPM, Bobbink R, Roelofs JGM (2000) Natural nitrogen filter fails in polluted raised bogs. Glob Chang Biol 6: 583-586. doi:10.1046/j.1365-2486.2000.00342.x

Limpens J, Berendse F, Klees H (2003) N deposition affects N availability in interstitial water, growth of Sphagnum and invasion of vascular plants in bog vegetation. New Phytol 157:339-347. doi:10.1046/j.1469-8137.2003.00667.x

Limpens J, Berendse F, Klees H (2004) How phosphorus availability affects the impact of nitrogen deposition on Sphagnum and vascular plants in bogs. Ecosystems (N Y, Print) 7:793-804. doi:10.1007/s10021-004-0274-9
Limpens J, Heijmans MMPD, Berendse F (2006) The nitrogen cycle in boreal peatlands. In: Wieder RK, Vitt DH (eds) Boreal Peatland ecosystems. Springer-Verlag, Berlin Heidelberg

Malmer N, Svensson BM, Wallén B (1994) Interactions between Sphagnum mosses and field layer vascular plants in the development of peat-forming systems. Folia Geobot Phytotaxon 29:483-496

Nadelhoffer KJ, Giblin AE, Shaver GR, Laundre JA (1991) Effects of temperature and substrate quality on element mineralization in six Arctic soils. Ecology 72:242-253. doi: $10.2307 / 1938918$

Ohlson M, Malmer N (1990) Total nutrient accumulation and seasonal variation in resource allocation in the bog plant Rhynchospora alba. Oikos 58:100-108. doi:10.2307/356 5365

Shaver GR, Chapin FS (1980) Response to fertilization by various plant growth forms in an Alaskan tundra: nutrient accumulation and growth. Ecology 61:662-675. doi: $10.2307 / 1937432$

Shaver GR, Chapin FS (1995) Long-term responses to factorial, NPK fertilizer treatment by Alaskan wet and moist tundra sedge species. Ecography 18:259-275. doi:10.1111/ j.1600-0587.1995.tb00129.x

Stevens CJ, Dise NB, Mountford JO, Gowing DJ (2004) Impact of nitrogen depostition on the species richness of grasslands. Science 303:1876-1879. doi:10.1126/science. 1094678

Tomassen HBM, Smolders AJP, Limpens J, Lamers LPM, Roelofs JGM (2004) Expansion of invasive species on ombrotrophic bogs: desiccation or high $\mathrm{N}$ deposition? J Appl Ecol 41:139-150. doi:10.1111/j.1365-2664.2004. 00870.x

Van der Hoek D, Van Mierlo JEM, Van Groenendael JM (2004) Nutrient limitation and nutrient-driven shifts in plant species composition in a species-rich fen meadow. $\mathrm{J}$ Veg Sci 15:389-396. doi:10.1658/1100-9233(2004)015 [0389:NLANSI]2.0.CO;2

Van Wijk MT, Clemmensen KE, Shaver GR et al (2003) Longterm ecosystem level experiments at Toolik Lake, Alaska, and at Abisko, Northern Sweden: generalizations and differences in ecosystem and plant type responses to global change. Glob Chang Biol 10:105-123. doi:10.1111/ j.1365-2486.2003.00719.x

Weltzin JF, Bridgham SD, Pastor J et al (2003) Potential effects of warming and drying on peatland plant community composition. Glob Chang Biol 9:141-151. doi:10.1046/ j.1365-2486.2003.00571.x

Wieder RK, Vitt DH (2006) Boreal peatland ecosystems. Springer-Verlag, Berlin, Heidelberg 